\title{
A Case Study of Production Practices and User Participation in an Advertising-Free Digital News Media Organisation
}

\author{
Sreekala Girija \\ Research Scholar, University of Hyderabad, Hyderabad, India, \\ g.sreekala@gmail.com
}

\begin{abstract}
The rising adoption of the Internet in India has contributed to the growth of digital news media organisations. Unlike the traditional advertiser-subsidised business model based on audience commodification, some of these new media firms rely on technology to offer news as a public service under an ad-less business model. Using a case study of Newslaundry, this article critically analyses whether interactive online technologies can help create media organisations untainted by the economic rationalities of capitalism. Following a mixed methodology approach that utilises data from 25 interviews with the Newslaundry team and mainstream journalists as well as a variety of text materials, the study finds that news loses its public good character due to Newslaundry's efforts to make profits. The analysis suggests that the interactive nature of the Internet does not automatically lead to democratic participation.
\end{abstract}

Keywords: digital news media, public service news, ad-less business model, social media, marketplace, user data

Acknowledgement: The author would like to thank her supervisor, Dr E. Sathya Prakash, and Prof. Christian Fuchs, for their suggestions and support.

\section{Introduction}

The increased adoption of Internet-related technologies and applications in India has supported the formation of a number of digital media organisations that do not depend on the traditional business model of audience commodification and corporate funding through advertisements (Sen and Nielsen 2016; Robinson, Grennan and Schiffrin 2015; Bearak 2014; Kohli-Khandekar 2013a). These media claim to offer public service news devoid of any corporate influence, with the help of interactive online technology. However, their growth has led to an erosion of their credibility, due to hypercommercialisation, their proximity to power centres, biased coverage, and censorship (Thakurta 2012; Bhushan 2013; Ninan 2014).

The nexus between corporate media and political power structures is neither a new phenomenon, nor is it limited to India. Writing on the US market, McChesney (2010, 400) states that large media "use their power to commercialise content to the greatest extent possible and if necessary, to protect their political interests". According to Herman and Chomsky's $(2002,2)$ propaganda model, concentrated ownership of the media, owner wealth, the profit orientation of the dominant mass-media firms, advertising as a primary income source, and the reliance of the media on information provided by governments can all work as filters in selecting content, thereby preventing anything that works against the interest of the big media firms from appearing before the public.

In this context, it is pertinent to ask whether interactive online technologies can actually create media organisations untainted by the economic rationalities of 
capitalism. To address this question, this article analyses the news production and distribution process of Newslaundry (https://www.newslaundry.com/), a for-profit digital news media organisation in India that does not accept advertisements. This is part of a larger study, and Newslaundry, is one of the three organisations selected using Patton's (1990, 169-170) "extreme or deviant case sampling" method. For the study, the researcher considered organisations that are established and led by former journalists, and that want to position themselves as public service news providers by rejecting advertising revenues. In a media landscape dominated by the advertisersubsidised, corporate owned/controlled mainstream media, such organisations were considered as deviant cases for the study.

Other considerations for selection included the firms' digital nature, funding patterns, and types of content. These conditions were pertinent to understanding the political economy of digital news media. Digital news media organisations that depended totally on the Internet for the production and distribution of news were selected for the study, and online sites with print or broadcast operations were excluded. Media sites that only host opinions and experts' views were not considered for the study, as the definition of 'news media' in the study design included organisations with formal editorial staff who conduct reportage and analysis from the field. In addition, the study did not consider organisations that have received funding from companies with close linkages to mainstream media either in the form of ownership or debt/equity funding. Readership of these media organisations, however, was not a criterion for selection, as no such data was available. When the study began in 2015, there were five media organisations in India that met these criteria for inclusion in the study. Of these five cases, two were for-profit firms and three were not-for-profit organisations. Although the researcher contacted all five organisations, only three agreed to participate in the research, and Newslaundry was one of them.

Founded by journalists Madhu Trehan, Prashant Sareen, Abhinandan Sekhri, and entrepreneur Roopak Kapoor, Newslaundry launched its operations in September 2012. Trehan, the co-founder and editor-in-chief of Newslaundry, was the founding editor of India's leading news weekly India Today and the country's first video news magazine Newstrack. Sekhri, the chief executive officer (CEO) and co-founder of Newslaundry, is also a trustee of Public Cause Research Foundation (PCRF), a NonGovernmental Organisation (NGO) founded by Delhi Chief Minister and Aam Aadmi Party (AAP) leader Arvind Kejriwal. Sareen and Kapoor are directors of Small Screen, a production house that makes documentaries, TV shows, and corporate videos. Newslaundry was incubated by Small Screen and later became a separate company. News Laundry Media Pvt Ltd, which runs the media portal Newslaundry, raised funding from Omidyar Network, which was established in February 2016 by eBay founder Pierre Omidyar and a number of angel investors. Eicher Motors' former chairman Vikram Lal, serial entrepreneur Abhijit Bhandari, Seedfund co-founder Mahesh Murthy, and Shashank Bhagat, through Unite India Periodical Pvt Ltd where he is partner and director, have also invested in Newslaundry. On May 16, 2016, the organisation had 22 employees. The site's main revenue source is reader subscriptions. Newslaundry's active subscriber number varies between 400 - 1,100 (Bansal 2016). Apart from subscriptions, Newslaundry sells news-related merchandise on its site for revenues. It also produces content for other media platforms like ScoopWhoop, one of the largest youth portals in India.

This article's aim is to understand online technologies' potential to offer a participatory media space devoid of corporate influence and the capitalist logic of commodification and commercialisation. Although the article employs a case study 
approach, it compares the organisation under study to a market dominated by advertiser-subsidised mainstream media in order to identify differences and similarities in ad-less media's production and distribution processes. In doing so, the article aims to contribute to the study of the political economy of digital news media and technology.

The article draws on mixed methods research, including 25 interviews with Newslaundry founders, editorial staff, and mainstream journalists and consultations of a wide variety of text materials. The study demonstrates that it is almost impossible for an ad-less digital news organisation to escape the capitalist logic of production and offer news as a public service. This is because such media operate in a market economy, where large corporations own and operate technology and related infrastructure.

The following section discusses the Indian media market and provides a brief historical overview of the way media is owned and operated in the country. The third section details the critical frameworks and the importance of using critical theories to analyse the research data. This is followed by a section on research design and an empirically supported analysis on the limitations of the Newslaundry's public service news model. The article also examines technology's role in the commodification of adless digital media and the difference between user participation and participatory democracy.

\section{The Indian Media Market}

Research suggests that the commercialisation of Indian media started even before the country initiated economic liberalisation in 1991. Robin Jeffrey (1994) contends that capitalist enterprises were present from the attainment of independence in 1947 . He argues that the country's three newspaper monitoring bodies - The Audit Bureau of Circulations (ABC), the Registrar of Newspapers for India (RNI), and the Indian Readership Survey (IRS) - represent a stage in the evolution of the Indian state's economic structure, the impact of advertising, and the state's effort to control media through advertising. The Indian state has always played a major role in the media industry, as did the colonial government that preceded it (Thomas 2010, 107-108). The Indian government has always kept a tight leash on the media through regulations, and the broadcast segment was a government monopoly owned by the state until 1992 . Corporate control in the broadcast industry began in 1992 with the launch of Star Television by a Hong Kong-based group. Prior to this, broadcasting was the monopoly of the state-owned enterprise Doordarshan.

The motivations of Indian news organisations have long been linked to profit and political influence. According to the First Press Commission report published in 1953, proprietors continued to operate newspapers because of the support provided by a domestic economy flush with post-World War II profits. Owners of print businesses had the opportunity to wield influence in public affairs (Kohli-Khandekar 2013b, 19-20).

The present media scenario is a continuation of this trend. Desai (2012) argues that in the twenty-first century, journalism entails giving visibility to brands rather than agitating against power structures, and that when profiteering became media companies' primary objective, journalism lost its character as a provider of information for the public good. Even the expansion of Indian regional dailies in the 1980s and 1990 s reflects the steady flow of advertising revenues (Jeffrey 1997). Ninan (2007, 201) also describes how circulation incentives and advertising were able to underwrite Hindi dailies' localisation.

Corporate control and political influence in the media industry are growing in India with the rise in mergers and acquisitions. In 2012, the Aditya Birla Group acquired a 
$27.5 \%$ stake in Living Media India, which publishes influential magazines such as India Today and Business Today (Datta and Sheikh 2012). Media reports (Bahree 2014; Pahwa 2014) indicate that in a complex deal initiated in 2012, Reliance, a large Indian conglomerate, acquired Network 18, a leading player in the broadcast segment. This acquisition gave Reliance majority control over the regional broadcaster ETV.

Commercialisation and corporate control have resulted in the loss of editorial independence. Arun (2014) argues that the state and big businesses use instruments such as advertising withdrawals and defamation notices to threaten journalists. Today, India has over 135 news channels, a third of which are owned by politicians and real estate entrepreneurs. Politicians own over $60 \%$ of the country's local cable systems, and they block at will channels they do not control. After the 2009 general elections, it came to light that some of the largest newspapers accepted bribes from candidates for the publication and suppression of stories (Kohli-Khandekar 2014).

Corporate control is also extreme. Circulation revenues constitute just $5-15 \%$ of English newspapers' income, and television news in India is almost completely dependent on advertising. Unlike international broadcast companies, which generate $55 \%$ of their revenue from subscription or pay, in India, advertising contributes $80 \%$ of the average news channel's revenues (Kohli-Khandekar 2013b, 90). Consequently, as Bhushan (2013) has noted, in the television newsroom "the promoter's fancies and political preferences have taken precedence over editorial judgment".

The state of affairs prevailing in India has triggered the Telecom Regulatory Authority of India (TRAI), the country's telecom and media regulator, to recommend the restriction of corporate media ownership by prohibiting religious bodies and government-funded entities from entering the broadcasting business (TRAI 2013, 2627). However, in a media market like India's, where the government itself is a large advertiser (Dubbudu 2015) and a major beneficiary of the present media-political power structure, these recommendations are yet to be translated into policies.

The more damaging development has been the submissiveness displayed by the mainstream Indian media in the face of the pressure tactics used by the right-wing Bharatiya Janata Party (BJP) government in power at the Centre. Nielsen (2017) writes that there is a "creeping quiet in Indian journalism" with journalists admitting that there is "a climate of fear". Mody (2018) attributes the displeasure of the central government as the reason for the exit of many senior editors in India. She goes on to point out that the mainstream media blanked out these incidents and the posts by some of these editors on social media.

The evidence suggests that, guided by the capitalist logic of commodification and commercialisation, mainstream media in India are focused on reinforcing and perpetuating economic and political power structures, thereby undermining the role of the media in a democratic society.

\section{Conceptual Framework}

The popularity of interactive digital technologies and Internet-related applications such as social media has triggered a large number of studies that highlight the participatory nature and emancipatory potential of these technologies. Benkler (2006, 30-32) states that the Internet "expands its reach by decentralising the capital structure of production and distribution of information, culture, and knowledge". He argues that the Internet can help reverse the "concentration and commercialisation of cultural production" by opening up alternative courses of action for people as individuals and as social actors. Jenkins $(2006,4-9)$ talks about the "participatory culture" brought about by media convergence and the emergence of "newly empowered", "active" and "socially 
connected" consumers. He contends that participatory culture has led to "an alternative source of media power". Picard argues that the digitisation that has created convergence between the media, computing, and telecommunications industries has in turn increased "flexibility and speed, create[d] economies of scope and integration that change the economics of content distribution, and shift[ed] greater control to consumers by allowing them to select, filter, search, control, and participate in multiple forms of communication" (Picard 2011, 6).

However, the relationship between technology and society is more complex than these studies suggest, prompting many critical scholars to question the deterministic approach. As Fuchs $(2009,75)$ remarks, "the task of critical Internet theory is to discuss how the fundamental concepts that characterize modern society and its negation can be applied to the relationship of the Internet and society so that they function as critical categories". In accordance with Marxian dialectical materialism, Fuchs identifies antagonistic structures in the Internet system. Like the antagonistic forces of competition and cooperation which shape capitalist society, online techno-social practices are also characterised by opposing forces. The commodification of information leads to restricted access and transforms information into a private good. Fuchs considers Google, Yahoo, YouTube, and social networking sites such as Facebook as "commodified Internet space", as they are governed by accumulation logic and offer free goods or platforms to attract users and sell space to advertisers $(2009,80)$.

Andrejevic also questions some scholars' tendency to automatically associate interactive participation and democratic empowerment. He states that "a critical media studies 2.0" should not be limited to "elaborating upon the dramatic transformations in media technologies and their uses" $(2009,36)$. Critical studies on new media technologies, according to Andrejevic (2011, 97), should highlight the difference between "access to the means of online content production and ownership or control over these resources".

This article draws on these critical perspectives to understand Newslaundry's news production and distribution process and analyses the relations of production embedded in this process. It also scrutinises ad-less digital media's technology-aided low-cost production and distribution process to understand its potential to offer a participatory space for democratic interaction.

\section{Methodology}

This article is part of a larger exploratory study of the political economy of digital news media in India. The study follows a qualitative approach to analyse three case studies, as the subject of the investigation - ad-less digital news media - is not well understood or covered in Indian academic research. The researcher adopted a multiple case study approach to ensure methodological rigour: Miles and Huberman $(1994,29)$ argue that such an approach helps in "strengthening the precision, the validity and stability of the findings". To test the study's feasibility, the researcher conducted a pilot study in 2015. This study report was used to frame the research questions and interview questionnaires.

Empirical evidence for this article was collected by integrating qualitative methods of three types. The first was the 10 semi-structured interviews conducted with the founders, editorial staff, and contributors of Newslaundry between May and August 2016. In order to contextualise and build on the interview data, the researcher also used a wide assortment of texts related to Newslaundry, including news reports, trade 
material, research reports, published interviews with the founders, and editorial information on the site; as well as informal interviews with mainstream journalists.

For the semi-structured interviews, a questionnaire consisting of 25 questions was sent to the participants in advance. The questions focused on Newslaundry's revenue model, funding, its reasons for choosing an ad-less business model, its use of technology, and its audience/readers and their participation in news production and distribution. The interviews were recorded and were transcribed manually. The transcriptions were later sent to the interviewees for their approval. For the informal interviews with mainstream media journalists, the researcher used a purposive sampling method. Twenty-three journalists were contacted. These individuals were professionally acquainted with the founders and editorial staff of the three digital news media under study and had over 10 years of experience in mainstream media (print, TV, or both). Of the 23 journalists, 15 agreed to participate, and the researcher conducted face-to-face informal interviews with them between October 2015 and March 2017. For the informal interviews, no formal questionnaire was used. The researcher provided detailed information regarding the study's purpose and scope and possible talking points at the time of seeking the interviewees' participation. As part of this, emails were sent to all of them and later followed up on phone to ensure that they received the communication and that they understood the research objectives. Talking points mainly covered the journalists' perspective on digital news media space in general and ad-less media in particular; the advantages and disadvantages of ad-less revenue models; and the principles that guide the functioning of such media in a corporate-dominated communication industry. The participants made it clear that they were giving interviews in their personal capacity as they did not have permission from their organisations to participate in the research. These interviews were not recorded, as the participants preferred informal interactions. The researcher took notes during the interviews and clarifications were sought whenever needed during the subsequent data analysis. These interviews allowed the researcher to gain insight into the differences and similarities between ad-less digital media and advertiser-subsidised mainstream media. The interview data were analysed using thematic coding (Flick 2009, 318-323).

One of the limitations of the article is that it is a case study. As a result, it may not represent every ad-less digital news media organisation in India. Although it offers a critical understanding of structural patterns, use of technology and the challenges faced by a digital news media organisation trying to move away from the advertisersubsidised business model, the analysis cannot be extrapolated to other digital news media organisations in India. Another limitation is the lack of data on readership and revenues of various digital news organisations in the country for comparison. Even the interview participants from Newslaundry refused to share any data on their readership and revenues.

\section{Findings and Discussion}

\subsection{For-Profit Company vs. Public Service News}

In interviews, the founders of Newslaundry have stated that their objective was to produce public-service journalism and that the business model of their for-profit organisation differs completely from that of the traditional media, as it depends on public contributions for revenues. A, ${ }^{1}$ co-founder of Newslaundry, says that "when the

\footnotetext{
${ }^{1}$ Interview participants are not identified by name in order to protect confidentiality.
} 
public pay, the public is served and when corporations pay corporations are served, or when the government pays, the government is served. Lot of news media just survives on government advertising, otherwise, they wouldn't be around. It is patronage basically".

The Newslaundry founders are not against capitalism or markets. Their aim was to disrupt the market to create a new market. As A explained: "Markets are a reality in the world and they work in a lot of ways. They are flawed in a lot of ways as well. You have to be conscious of both. But anywhere in the world, if you want to be a disruptor and want to disrupt the entire structure of an industry, you can't do it on the ground. You have to break the economic model for the industry to change".

With only foundation grants at its disposal, A did not think a non-profit model like a trust could disrupt the market or change the news model. He maintained that "[...] you have to incentivise the news. You can incentivise independent news media. You have to disrupt the market using the same tools offered by the market". In the competitive world of news media, where Newslaundry aims to take on The Times of India, the founders feel capital deployment is necessary to establish their venture. Published in India, The Times of India is the largest circulated English-language daily in the world. The co-founder of Newslaundry explained that one has to have a significant amount of capital to deploy in order to compete with the biggest in the market, and this cannot come from grants; stating that "it is a business and we are fine with corporate capital". The founders of Newslaundry emphasised that they were selective about who they took money from. They did not encourage any kind of editorial interference from the corporate investors. The co-founder said there was a list of corporate investors they would not touch for fear of editorial interference.

This line of argument embodies what Fuchs (2014a, 56-57) calls "essentialism", which does not see phenomena as historical processes. The Newslaundry founders believe that markets and capital are inescapable realities that are here to stay. McChesney $(2010,421)$ says that markets cannot effectively regulate media: "Competition in the market forces firms to give people what they want" as long as they can make profit.

M, another Newslaundry founder, states that "[...] we chose this business model because we did not want to get influenced by advertisers. We believe Indians are willing to pay for their news". D, an editor at Newslaundry, says that journalism is expensive and readers are unaware about the investment required to compile a story: "It is an exhausting business. And, for that exhausting business, you pay Rs 3 or Rs 7 for 20 pages of 'news' that is kind of obscene". D thinks news consumers should reflect on the kind of news they are getting and the kind of news they want. As Newslaundry targets English-speaking people, D believes affordability is not a problem for its readers. These data show Newslaundry considers news organisations as business entities and readers as news consumers. As $P$, a mainstream journalist, noted, there is no doubt that Newslaundry is trying to do something different, although it is difficult to predict whether this model is sustainable or not: "You have to understand that in our country readers do not have the habit of paying for news. But the site is still dependent on corporate capital. Newslaundry also sells its brand-related merchandise on its site like an e-commerce site".

Initially, content was completely free on the Newslaundry site. A paywall for some content was introduced in 2017. Newslaundry plans to shift more content behind the paywall so that most of its news is accessible only to subscribers (Bansal 2016; Shashidhar 2017). This new policy structure contrasts starkly to a statement made by one of the co-founders in an article on June 28, 2014, where he claimed that the site 
did not want to use a paywall; Newslaundry content should be available to young people, especially students, who would not be able to pay. This change in stance can be attributed to Newslaundry's effort to become profitable as revealed by an editorial podcast on December 4, 2016 (NL Hafta 96). Although Newslaundry does not disclose its exact revenues, NL Hafta 96 mentioned that the company had not yet broken even.

Splichal $(2007,255)$ states that "public service media must be a service of the public, by the public, and for the public". Public service media (PSM) should be financed, controlled and produced by the public. Murdock $(2018,47)$ says that PSM should help keep the online space as a "universal public sphere" for open, democratic deliberations. Fuchs and Sandoval $(2015,171)$ say that unlike capitalist media, public service media "reject the for-profit imperative and are not the private property of capitalists". McChesney $(2010,147)$ lists the BBC as a striking example of a noncommercial public service media. He also points out the need to develop new "forms and structures of non-profit, noncommercial" public media to cater to the pluralistic needs of the public.

Following these ideas, the researcher considers public service media to have a notfor-profit, non-commercial character, where readers as citizens own and produce the media. However, in Newslaundry's case its for-profit structure, private ownership and subscriber-centric revenue model undermine its position as public service media. Its relationship with readers as consumers of news further complicates its position. In addition, Newslaundry's engagement with its readers through third-party service providers indirectly leads to the misuse of their personal information: this is explained in the following sections. Although it is an ad-less media form, Newslaundry is still a capitalist media that aims to challenge the competition in the market place by replacing one business model with another in order to make money.

\subsection{Ownership, Control and Exploitation of Communication}

Newslaundry launched its digital news business because of the rising popularity of the Internet and the growing consumption of online content in India. Unlike traditional big media technology that prevented other types of business models from functioning, the Internet, says A, "allowed us to try out a different business model". Here, A is talking about the cost advantages the Internet can offer. Unlike traditional media such as print and broadcast, the resources required to start an online news organisation is very low. In addition, the Internet makes it possible to distribute news products for free and also provides convenient payment options. Another reason for Newslaundry's choice of the digital medium was the nature of the Internet technology; specifically, the fact that it does not allow for government censorship. A says: "You cannot censor the Internet, whereas you can censor a broadcast. You are using airwaves, which is a public property and which has to be licensed". M pointed out that the use of the Internet in India is growing, with more and more people getting online. "Technology brings down the cost of news production and distribution, as a digital news media organisation does not have to invest in a printing press or distribution channels".

However, contrary to the Newslaundry founders' perception, technology can be controlled by the government and powerful interests. The Indian government has always tried to control dissenting voices through draconian laws such as the Information Technology Act 2000 that have led to the arrest of many people, including teenagers, for their social media posts. The Supreme Court struck down Section 66A of the Act in 2015 (Sriram 2015). A 2015 report by the Indian news agency Press Trust of India (PTI) that came out after the court ruling suggests that the Indian government is working on restoring provisions in Section 66A to control people's online activity in 
order to ensure national security. Governments in India - both the Centre and states have previously shut down the Internet for political reasons. Indeed, this is almost a regular activity in conflict-ridden Kashmir. Many see these shutdowns as an effort by the government to silence people's voices (Raha 2016; Saha 2017). In 2015, the Gujarat state government shut down the Internet to avoid an upturn in the Patel community's protest movement for reservations (Johari 2015). Haryana state government had blocked Internet services during a protest by the state's Jat community (IANS 2016). India's telecom regulator, in fact, allows for shutdowns. In the event of political turmoil, government authorities, mostly police, will ask Internet Service Providers (ISPs) to shut down citizens' Internet access (Sushma 2018; Agarwal 2018). When there is a total Internet shutdown, people cannot access any digital media, including Newslaundry.

The state and central governments, powerful individuals and corporates in India have always used laws to control the media (India Today 2017). Poorly-defined existing laws are sufficient to control the digital media communication. A defence analyst/ journalist was arrested in Delhi in October 2018 for posting a satirical Twitter video, while a woman in Kerala was arrested in November for her Facebook post. Both were arrested for "hurting religious sentiments". What complicates matters is that in both cases courts refused to come to their rescue: both people were sent to jail, as they were denied bail by the Indian Supreme Court and Kerala High Court respectively (The Wire 2018; Times of India 2018). When even sentences uttered in a seminar can lead to sedition charges in India (The Hindu 2016), it is almost impossible to expect the Internet and technological tools to establish a free media space.

Although the government has approved the principle of net neutrality, TRAI recommendations are expected to benefit large companies like Reliance Jio Infocomm and Bharti Airtel (Pandey 2017). These are integrated operators, which own both telecom infrastructure and content, and TRAI has decided to exempt content delivery networks from the regulation. Reliance is India's largest company, and it is also one of the largest media owners in the country (Thakurta 2014). With significant telecom infrastructure under its control, Reliance is likely to attain an edge over others, especially small digital media companies like Newslaundry that do not own or control telecom infrastructure, suggesting the difference between access to the means of production and ownership of it (Andrejevic 2011, 97).

Technology, especially social media, plays a major role in Newslaundry being discovered by people, as the media organisation depends on social media to market its content to attract readers. V, the head of technology at Newslaundry, considers social media like Facebook as more or less equivalent to news media. He thinks social media offer a great opportunity for media houses:

If you take any news organisation, I am sure at least $50 \%$ of their leads or stories come from social media, and half of their readers are social media users. There is no denial there. That is the platform and everything runs on top of it.

As A says, "[...] we use social media to attract visitors. We boost stuff on Facebook". As of May 2016, Newslaundry did not use any technological tools to enhance its presence on social media. "Our growth has been organic so far. We will now be using all other technological tools. But we cannot reveal our data analytics", says A. However, Newslaundry does not have any plans to host Google advertisements. It also will not enter into revenue-sharing agreements with social media like YouTube for its content, because, as A says, "that is not our model". 
Newslaundry founders did not rule out the possibility of tracking users to expand its reader base. "We do not track the visitor profiles. Not yet. But that does not mean we never will," says A. Currently, under its privacy policy, the organisation states that it uses a tool called MixPanel to collect users' personal information, such as name, email address, region and so on, to customise content and optimise its distribution. While Newslaundry guarantees not to share the collected information with any party, it states that "Newslaundry is neither responsible nor controls how other platforms and tools treat the data they collect". Although it states that MixPanel does not share personal information with any party, the site is silent about its use of social media and a particular comment management platform. Considering that Newslaundry's use of the latter two tools is extensive, this omission suggests that it does not employ any specific privacy protection tools for social media use. Even during the interviews, none of the interviewees talked about the privacy of social media users or the Newslaundry readers, or the exploitation of user data by social media platforms like Facebook. This further suggests that they have not considered the need for an alternative, commonsbased public service social media. In fact, in late 2016 Newslaundry launched its social influencer campaign, which encouraged users to share their online activities in exchange for gifts and free merchandise, thereby generating large amount of user data for itself and for social media corporations.

Interviewees' perceptions about the use of social media suggest that Newslaundry is part of "communicative capitalism" (Dean 2010, 4-5), which relies on the exploitation of communication. Newslaundry uses social media platforms like Facebook to market its content in order to attract audiences as well as sell its merchandise. It regularly posts news content and links on social media for this purpose. This process creates new networks of communication, where readers are engaged in enjoyment and production. But their communications are also being monitored and exploited by companies. While Newslaundry uses readers' personal communication to market its content, social media companies gain from users' unpaid labour, where readers are engaged in producing content (Fuchs 2010, 191).

Social media platforms like Facebook and YouTube offer free space to users and media firms like Newslaundry as these organisations produce content that helps social media firms to expand their communication networks. The enormous amounts of personal data created on these platforms are monitored, collected and used for generating profit by social media platforms and data-mining companies. Social media companies allow third parties to access these data through Applications Programming Interfaces (APIs) for a fee: public and open APIs are a rarity in the commodified system. However, exceptions are there, as Twitter, for instance, offers three public APIs in addition to its premium offering. Facebook also used to allow third-party apps to access the data of the friends of app users. It is this facility that was misused by data consultancy firm Cambridge Analytica to collect information from millions of users (Bastos and Walker 2018).

India has the highest number of Facebook users in the world, and user behaviour on the Facebook website and Newslaundry's social media page can reveal not only their personal preferences but also their political affiliations. This in turn can be used by political parties for their advantage. In fact, the ruling right wing Bharatiya Janata Party and opposition Congress along with various regional parties had previously used the services of Cambridge Analytica in elections (Verniers and Hangal 2018; Kumar 2018). In other words, user behaviour on various social media platforms make them susceptible to manipulated news feed, including fake news, and Newslaundry inadvertently plays a role in this exploitation. However, Newslaundry is not alone in this 
process: every media firm and organisation with a social media page that does not employ privacy protection tools generates user data that can be harvested by social media platforms and their partner companies for profits. Using the psychoanalytic notion of fetishism, Dean $(2010,5)$ remarks that "ideology is what we do, even when we know better"; it is this ideology that drives users of social media to continue to do what they do even though they know companies collect their personal data.

\subsection{Participation vs. Participatory Democracy}

All the interview participants emphasised the potential of Internet technology to democratise the news space. $M$ asserted that everything about technology is democratic, as it offers immediate feedback and readers' reactions. All participants agreed that users were gaining more control over news production due to interactive technology. While all the Newslaundry interviewees were optimistic about the interactive nature and democratic potential of the digital medium, my analysis suggests that content production is still completely under the producers' control.

"Comments have made me introspect all the time. I go through comments regularly. I take audience reaction seriously. But I never feel compelled to write in a particular way to be accepted by the audience", says P, an editorial staff member. D feels that the democratic potential of the Internet helped one to be a better writer. At the same time, she adds: "I don't go through the comments because in my experience someone who is going to give a reasoned comment will email me or get in touch with me in person. So, someone who is sort of typing in the comments section, I think they are doing that to get a little bit of attention for themselves".

$P$ says that the real-time engagement has given users more power: "There is definitely democratic potential. We are closer to the readers now with technology. It also keeps you on your toes". However, she does not think producers are losing control. As she explains: "It is not like you can write anything you want to. There will be checks in place. Yes, here checks can happen at boss' side and readers' side. But I don't think that has affected the control. We are careful that way. Pleasing people is a very tough thing to do".

AM, a contributor to digital news media organisations, says he never felt compelled to look back or change his writing style based on feedback: "Anybody pointing out factual errors, I correct it". He points out that he has not come across editors looking at comments sections and changing their news style or news reports, but adds that "it does not mean editors are not doing it". He reveals that when he started writing for media he used to engage with readers, but this has changed: "Now I have just quit it. I feel so much commentary going on that you feel let it be".

Another unintended consequence of feedback sections seems to be that journalists' and editors' fearlessness has been compromised. A says that "journalists now fear of [sic] not being popular". But overall, he felt the interactive potential of the Internet to be a good thing because it tells the journalist or editor where s/he stands. Newslaundry does not make content based on readers' feedback. "You have to serve the public but not anyone in particular", says A. He believes that there are certain kinds of people who pay for independent media: "The people who pay for good content do it because it is good and not because you are toeing their line. And those are the people who we target". Newslaundry considers ideology-based payments as something too dangerous to pursue: "You never know which way it will go, because in our organisation, we have all sorts of ideological positions".

These statements are fraught with contradictions. Despite positioning itself as a public service news provider, Newslaundry does not take into consideration readers' 
feedback for content production. It is still the producers who decide what "good content" is. On the one hand, Newslaundry journalists are of the opinion that the Internet has democratised the media space and that comments have made them introspect, and on the other, they are not willing to interact actively with the readers. Going by their statements, the Internet's democratic potential stems from its "interactive nature". Fuchs $(2014 a, 65)$ states that "an Internet dominated by corporations that accumulate capital by exploiting and commodifying users" can never be considered as participatory democracy. Extending Carpentier's political concept of participatory democracy (quoted in Fuchs $(2014 a, 56)$ ) that conceives of participation as equal power relations in decision-making processes, Fuchs says that a truly participatory media democracy must also be an ownership democracy. In this sense, Newslaundry does not create a space for participatory democracy, as it supplies audience commodity to social media corporations, as demonstrated in the previous section. Newslaundry's readers are neither involved in decision-making processes, nor do they own Internet-related resources. As Herman $(1995,215)$ says, in a democratic media "the users would determine their own needs and fix the menu of choices either directly or through their closely controlled agents".

Furthermore, the interaction space Newslaundry provides through its comments section is mediated by capital. Newslaundry does not allow anonymous comments. "One has to use either social media login or the Disqus platform to post comments. This greatly compromises users' privacy and exposes them to targeted advertising by the US-based company Disqus. Readers can of course read Disqus' policies through a link on the site. Mainstream media encourages social media login for comments, but that is not mandatory", says T, a journalist with a leading daily. Disqus' revenue model is not markedly different from those of free social media platforms. The company tracks and collects user data from sites that use its commenting system: "It follows a user's activities across sites that use Disqus, even if the user is logged out" (Couts 2012). On the Disqus site under "Privacy Policy", the company makes it clear that it uses cookies to collect information about users and that it shares personally-identifiable information and encrypted email addresses with third-party business partners and agents. By using Disqus' service, Newslaundry becomes its partner and a supplier of users as a commodity to the US-based company. While Newslaundry does not receive any revenue from advertisers, it helps generate advertising revenue for transnational monopolies like Google, Facebook, Twitter and Disqus, and becomes their partner in this process.

Apart from profit accumulation by corporations, surveillance and compromises on users' privacy of this kind have larger political implications. Although the Indian Supreme Court has declared privacy a fundamental right (Mittal 2017), in the case of state overreach it has pointed out the need to maintain a balance between individual rights and "legitimate concerns of the state". In addition, establishing jurisdiction over data collected by US-based companies with data servers across the globe is a major challenge. A Philadelphia court has ruled that the US authorities have the right to access data from American Internet companies, even if they are stored on foreign servers. This suggests that personal data on Facebook, Twitter, Google and Disqus will be open to surveillance by the US authorities (Bershidsky 2017).

\section{Conclusion}

The study has shown how multiple factors undermine the potential of Newslaundry to function as a public service news provider. This analysis is in line with the arguments of Murdock (2018), Splichal (2007), McChesney (2010) and Fuchs and Sandoval 
(2015) as the organisation's for-profit, privately-owned structure and the nature of its engagement with its audience makes Newslaundry a capitalist media form. However, what complicates such an analysis is the conditions under which the media system operates in India. The country lacks an independent non-profit public service media. Its public broadcasting entities are not only funded but also controlled by the government. Private media in India is almost totally dependent on advertising revenues from private corporations and state and central governments. The media in general are also vulnerable to defamation suits and government control. These factors limit the potential of the Internet and Newslaundry to establish the "digital commons" as envisaged by Murdock $(2018,50)$. Therefore, the study takes a critical position that acknowledges the potential of Newslaundry to challenge the existing media in the country by making an effort to offer an alternative media space that is not influenced by recurring revenues from the government or corporate advertisers. At the same time, the analysis challenges Newslaundry's claims of being a public service news provider by pointing out the limitations of its capitalist structure.

Newslaundry's subscription-centric revenue model requires constant marketing of its content through social media. Newslaundry's use of social media is different from that of a public service media like the BBC, as Newslaundry has to attract more readers and turn them into subscribers to gain revenues and make a profit. As a result, news attains a commodity form. As a public-owned and funded broadcaster, the BBC does not have to sell news to make a profit. Newslaundry's production process and its engagement with the audience also produce the user/audience commodity. However, as an ad-less media model, Newslaundry does not sell this commodity and the audience commodity does not play any role in its capital accumulation process. Figure 1 represents the capital accumulation process of Newslaundry and Figure 2 is that of ad-financed companies like social media and Disqus.

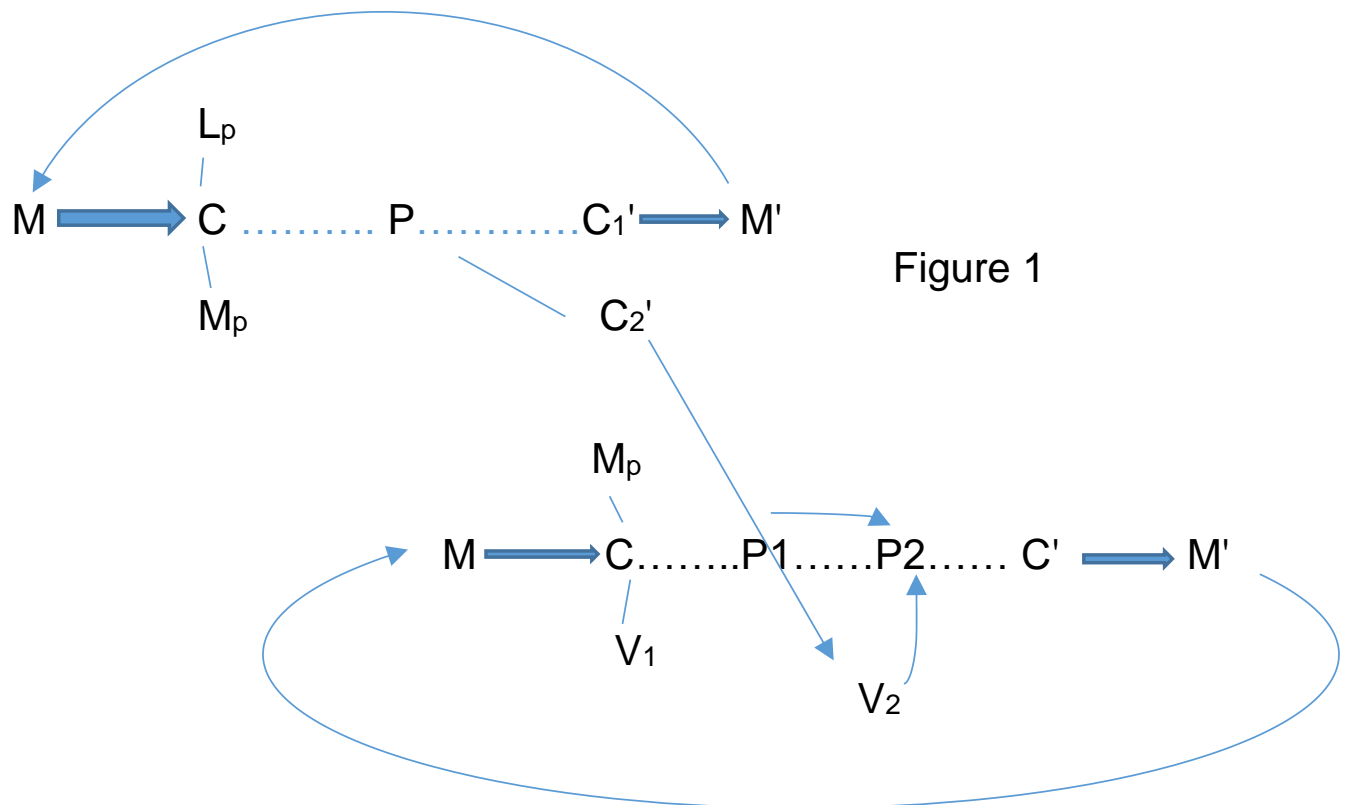

Figure 2 
In these figures $\mathrm{Lp}$ is labour power and $\mathrm{Mp}$ is the means of production, which include infrastructure and technology. Newslaundry's production process creates two commodities - news $\left(\mathrm{C}_{1}{ }^{\prime}\right)$ and audience $\left(\mathrm{C}_{2}{ }^{\prime}\right)$. As labour power adds value to the commodity, $\mathrm{C}_{1}{ }^{\prime}=\mathrm{C}+\Delta \mathrm{C}$. Newslaundry indirectly passes on this audience commodity to its social media partners and comment management platform, thereby becoming part of the capital accumulation process of the ad-financed media corporations. As Fuchs $(2015,145-150)$ says, in the case of ad-financed corporations, labour power includes paid labour (V1) as well as unpaid labour (V2) and Newslaundry's audience commodity becomes part of this V2 along with other users of social media.

The present researcher therefore argues that Newslaundry functions like a consumer goods company, wherein it gains the majority of its revenues by directly selling news and its capital accumulation process, close to what Marx (1893, 28-30) suggests. However, the user commodity it supplies enters the capital accumulation circuit of social media, contributing to their profit. Considering that Newslaundry has not yet started making any profit ( $\mathrm{M}^{\prime}$ is not $\geq \mathrm{M}$ ), the major beneficiaries of this entire accumulation process are social media corporations.

\section{References}

Agarwal, Ravi. 2018. The inside story of how India shuts down the Internet in Kashmir. Quartz India, October 3. Accessed November 10, 2018. https://qz.com/india/1408071/how-india-shuts-down-internet-in-kashmir/

Andrejevic, Mark. 2011. Social Network Exploitation. In A Networked Self: Identity, Community, and Culture on Social Network Sites, edited by Zizi Papacharissi, 82-111. New York: Routledge.

Andrejevic, Mark. 2009. Critical media studies 2.0: An interactive upgrade. Interactions: Studies in Communication and Culture 1 (1): 35-51.

Arun, Chinmayee. 2014. Private censorship and the right to hear. The Hoot, July 17. Accessed July 10, 2016. http://www.thehoot.org/free-speech/media-freedom/private-censorship-and-the-right-to-hear-7652

Bahree, Megha. 2014. Reliance takes over Network18: Is this the Death of Media Independence? Forbes, May 30. Accessed December 29, 2018. https://www.forbes.com/sites/meghabahree/2014/05/30/reliance-takes-over-network18-is-this-the-death-of-media-independence/

Bansal, Shuchi. 2016. The Big Paywall Question. Mint, October 27. Accessed November 15, 2016. http://www.livemint.com/Opinion/wezx5YVSzOkIE6EOxU5ZhL/The-big-digital-paywall-question.html

Bastos, Marcus and Shawn T. Walker. 2018. Facebook's data lockdown is a disaster for academic researchers. The Conversation, April 11. Accessed November 5, 2018.

http://theconversation.com/facebooks-data-lockdown-is-a-disaster-for-academic-researchers-94533

Bearak, Max. 2014. Global Digital News Brands See Growth Opportunity in India. The New York Times, May 25. Accessed December 21, 2016. https://india.blogs.nytimes.com/2014/05/25/global-digital-news-brands-see-growth-opportunity-in-india/? $\quad r=0$

Benkler, Yochai. 2006. The Wealth of Networks: How Social Production Transforms Markets and Freedom. New Haven: Yale University Press.

Bershidsky, Leonid. 2017. Does US have the Rights to All your Google \& FB Data? The Economic Times, February 9. Accessed 29 December, 2018. http://epaperbeta.timesofindia.com/Article.aspx?eid=31818\&articlexml=Does-US-have-the-Rights-to-All-your$\underline{09022017006033}$ 
Bhushan, Sandeep. 2013. The death of the reporter. The Hindu, October 18. Accessed December 29, 2018. http://www.thehindu.com/opinion/lead/The-death-of-the-reporter/article12312640.ece

Couts, Andrew. 2012. Digital Trends, August 30. Accessed December 8, 2016. http://www.digitaltrends.com/web/top-100-websites-how-are-they-tracking-you/

Datta, Aveek and Aminah Sheikh. 2012. Aditya Birla to pick up 27.5\% stake in Living Media. Mint, May 18. Accessed March 4, 2016. https://www.livemint.com/Companies/hzwX3zKAVEL1g8SQgxFCWM/Aditya-Birla-to-pick-up-275-stake-in-Living-Media.html

Dean, Jodi. 2010. Blog Theory. Cambridge: Polity Press.

Desai, K. Mira. 2012. Changing Face of Indian Journalism: Political Agitations to Economic Alliances. Media Watch 3 (1): 03-08. doi:10.15655/mw/2012/v3i1/53610

Dubbudu, Rakesh. 2015. The Central Government spent more than 6000 crore on publicity in the last 11 years. FACTLY, July 11. Accessed January 5, 2017. https://factly.in/the-central-government-spent-more-than-6000-crore-on-publicity-in-the-last-11-years/

Flick, Uwe. 2009. An Introduction to Qualitative Research [4th edition]. New Delhi: Sage Publications India.

Fuchs, Christian. 2015. Culture and Economy in the Age of Social Media. New York: Routledge.

Fuchs, Christian. 2014a. Social Media: A Critical Introduction. London: Sage.

Fuchs, Christian. 2014b. Social Media and the Public Sphere. tripleC: Communication, Capitalism \& Critique. Open Access Journal for a Global Sustainable Information Society 12 (1): 57-101. Accessed December 29, 2018. https://www.triple-c.at/index.php/tripleC/article/view/552

Fuchs, Christian. 2011. An Alternative View of Privacy on Facebook. Information 2 (1): 140165. doi:10.3390/info2010140

Fuchs, Christian. 2010. Labour in Informational Capitalism. The Information Society 26 (3): 176-196.

Fuchs, Christian. 2009. Information and Communication Technologies and Society: A Contribution to the Political Economy of the Internet. European Journal of Communication 24 (1): 69-87. Accessed January 20, 2017. http://fuchs.uti.at/wp-content/uploads/ICTS EJC.pdf

Fuchs, Christian and Marisol Sandoval. 2015. The Political Economy of Capitalist and Alternative Social Media. In The Routledge Companion to Alternative and Community Media, edited by Chris Atton, 165-175. London: Routledge.

Herman, Edward. 1995. Triumph of the Market: Essays on Economics, Politics, and Media. Boston: South End Press.

Herman, Edward and Noam Chomsky. 2002. Manufacturing Consent: The Political Economy of Media [2nd edition]. New York: Pantheon Books.

Jeffrey, Robin. 1994. Monitoring Newspapers and Understanding the Indian State. Asian Survey 34 (8): 748-763.

Jeffrey, Robin. 1997. Advertising and Indian Language Newspapers: How Capitalism Supports (Certain) Cultures and (Some) States. Pacific Affairs 70 (1): 57-84.

Jenkins, Henry. 2006. Convergence Culture: Where Old and New Media Collide. New York: New York University Press.

Johari, Aarefa. 2015. Gujarat Internet ban: On Day Six, citizens have had enough of being patronised by the state. Scroll, September 1. Accessed December 12, 2016. https://scroll.in/article/752538/gujarat-internet-ban-on-day-six-citizens-have-had-enoughof-being-patronised-by-the-state

IANS. 2016. Internet services blocked in Haryana after protests turn violent. February 19. Accessed December 4, 2016. https://www.bgr.in/news/internet-services-blocked-in-haryanaafter-protests-turn-violent/ 
India Today. 2017. Jay Amit Shah to sue The Wire for Rs 100 crore over defamatory report. October 8. Accessed March 23, 2018. https://www.indiatoday.in/india/story/amit-shah-sonjay-shah-piyush-goyal-roc-narendra-modi-1060409-2017-10-08

Kohli-Khandekar, Vanita. 2014. Trai's take on media ownership. Business Standard, August 19. Accessed January 20, 2017. http://www.business-standard.com/article/opinion/vanitakohli-khandekar-trai-s-take-on-media-ownership-114081901350 1.html

Kohli-Khandekar, Vanita. 2013a. India online, on the go. Business Standard, November 18. Accessed January 4, 2017. http://www.business-standard.com/article/opinion/vanita-kohlikhandekar-india-online-on-the-go-113111801029 1.html

Kohli-Khandekar, Vanita. 2013b. The Indian Media Business [3rd edition]. New Delhi: Sage Publications.

Kumar, Aishwarya. 2018. Here's What the Websites of Cambridge Analytica, Partner Firms Say About Ties to BJP and Congress. News 18, March 21. Accessed November 3, 2018. https://www.news 18.com/news/india/heres-what-the-websites-of-cambridge-analyticapartner-firms-say-about-bjp-and-congress-1696061.html

Marx, Karl. 1893. Capital: A Critique of Political Economy, Volume II. Moscow: Progress Publishers.

McChesney, W. Robert. 2010. The Political Economy of Media. Delhi: Aakar Books.

Miles, Matthew and Michael Huberman. 1994.Qualitative Data Analysis: An Expanded Sourcebook. Thousand Oaks: Sage Publications.

Mittal, Priyanka. 2017. Right to privacy is fundamental: Supreme Court. Mint, August 25. Accessed December 7, 2017. http://www.livemint.com/Politics/7MJYb4WJXezaRdf8Sr1ubl/Privacy-is-a-fundamental-right-says-Supreme-Court-inhistor.html

Mody, Anjali. 2018. Media freedom in the Modi age: The cat-and-mouse game is set to get more fierce as 2019 nears. Scroll, August 13. Accessed November 1, 2018. https://scroll.in/article/889869/media-freedom-in-the-modi-age-the-cat-and-mouse-gameis-set-to-get-more-fierce-as-2019-nears

Murdock, Graham. 2018. Reclaiming Digital Space from Commercial Enclosure to the Broadcast Commons from Public Service Broadcasting to Public Service Media. In Public Service Media in the Networked Society, edited by Gregory Ferrell Lowe, Hilde van Den Bulk and Karen Donders, 43-59. Gothenburg: Nordicom.

Nielsen, Rasmus Kleis. 2017. A creeping quiet in Indian journalism? HuffPost, November 15. Accessed November 1, 2018. https://www.huffingtonpost.com/entry/a-creeping-quiet-inindian-journalism us 5a046be2e4b0204d0c1714bb

Ninan, Sevanti. 2014. Tackling private censorship in media. The Hoot, July 24. Accessed December 19, 2016. http://www.thehoot.org/media-watch/opinion/tackling-private-censorship-in-media-7664

Ninan, Sevanti. 2007. Headlines from the Heartland: Reinventing the Hindi Public Sphere. New Delhi: Sage.

Pahwa, Nikhil. 2014. How Reliance Industries acquired Network18: A detailed timeline of events. Medianama. May 30. Accessed June 12, 2016. http://www.medianama.com/2014/05/223-how-reliance-industries-acquired-network18-a-detailed-timelineof-events/

Pandey, Navadha. 2017. Trai backs net neutrality, Reliance Jio, Airtel stand to gain. Mint, November 29. Accessed October 5, 2018. https://www.livemint.com/Industry/ZtZlbiNrzhAD780oGxYXNP/Trai-backs-net-neutrality-in-recommendations-releasedtoday.html?utm source=scroll\&utm medium=referral\&utm campaign=scroll

Patton, Michael Quinn. 1990. Qualitative evaluation and research methods. Beverly Hills, CA: Sage.

Picard, Robert. 2011. Mapping Digital Media: Digitisation and Media Business Models. Open Society Media Program Reference Series No 5. London: Open Society Media Program. Accessed December 14, 2016. https://www.opensocietyfoundations.org/sites/default/files/digitization-media-business-models-20110721.pdf 
Raha, Shuma. 2016. Kashmir cut off: Why Internet bans are bad for democracy. The Hoot, July 20. Accessed October 5, 2016. http://www.thehoot.org/media-watch/digital-media/kashmir-cut-off-why-internet-bans-are-bad-for-democracy-9506

Robinson, J. J., Kristen Grennan and Anya Schiffrin. 2015. Publishing for Peanuts: Innovation and the Journalism Start-up. International Media, Advocacy, and Communications at Columbia University School of International and Public Affairs. Open Society Foundation's Program for Independent Journalism. Accessed January 4, 2017. http://www.cima.ned.org/wp-content/uploads/2015/11/PublishingforPeanuts.pdf

Saha, Abhishek. 2017. 'Scared of camera': Kashmir Internet shutdowns seen as an attempt to choke voices. Hindustan Times, April 30. Accessed December 5, 2017. http://www.hindustantimes.com/india-news/scared-of-camera-kashmir-internet-shutdowns-seen-as-anattempt-to-choke-voices/story-cQ4thHTsgSJi5t5gXsd0DM.html

Sekhri, Abhinandan. 2016. NL Hafta 96 [Podcast]. Newslaundry, December 2. Accessed January 7, 2018. https://www.newslaundry.com/2016/12/02/hafta-96-nabhajailbreak-congresss-twitter-handle-hacked-and-fidel-castro

Sen, Arijit and Rasmus Kleis Nielsen. 2016. Digital Journalism Start-Ups in India. Reuters Institute for the Study of Journalism. Accessed December 30, 2018. https://reutersinstitute.politics.ox.ac.uk/our-research/digital-journalism-start-ups-india

Shashidhar, K. J. 2017. Parts of Newslaundry's website goes behind a paywall. Medianama, January 18. Accessed February 20, 2017. https://www.medianama.com/2017/01/223newslaundry-goes-behind-paywall/

Splichal, Slavko. 2007. Does History Matter? Grasping the Idea of Public Service Media at its Roots. In From Public Service Broadcasting to Public Service Media, edited by Gregory Ferrell Lowe and Jo Bardoel, 237-257. Gothenburg: Nordicom.

Sriram, Jayant. 2015. SC strikes down 'draconian' section 66A. The Hindu, March 24. Accessed October 15, 2016. http://www.thehindu.com/news/national/supreme-court-strikesdown-section-66-a-of-the-it-act-finds-it-unconstitutional/article10740659.ece

Sushma, U. N. 2018. India's Internet shutdowns are costing the economy billions of dollars. Quartz India, July 31. Accessed November 10, 2018. https://qz.com/india/1341995/indiasinternet-shutdowns-cost-the-economy-billions-of-dollars/

Telecom Regulatory Authority of India [TRAI]. 2013. Consultation Paper on Issues relating to Media Ownership. New Delhi. Accessed December 27, 2016. http://www.trai.gov.in/sites/default/files/CP-Media Ownership final.pdf

Thakurta, Guha Paranjoy. 2014. What Future for the Media in India? Reliance Takeover of Network18. Economic \& Political Weekly 49 (24): n.p. Accessed January 2, 2016 http://www.epw.in/journal/2014/24/web-exclusives/what-future-media-india.html

Thakurta, Guha Paranjoy. 2012. Media Ownership in India: An Overview. The Hoot, June 30. Accessed December 10, 2016. http://www.thehoot.org/resources/media-ownership/mediaownership-in-india-an-overview-6048

The Hindu. 2016. 'Sedition' versus free speech. October 26. Accessed December 30, 2017. http://www.thehindu.com/opinion/editorial/Sedition-versus-free-speech/article13673138.ece

The Wire. 2018. No Relief from SC for Analyst Who Joked About Konark Temple. October 4. Accessed October 15, 2018. https://thewire.in/law/sc-bail-plea-analyst-konark-temple

Thomas, Pradeep Ninan. 2010. Political Economy of Communications in India: The Good, The Bad and The Ugly. New Delhi: Sage India.

Times of India. 2018. Kerala HC rejects anticipatory bail plea of activist Rehana Fathima. November 16. Accessed November 20, 2018. https://timesofindia.indiatimes.com/india/kerala-hc-rejects-anticipatory-bail-plea-of-activist-rehana-fathima/articleshow/66652686.cms

Verniers, Giles and Sudheendra Hangal. 2018. India's political parties have mined voters' psychographic data for years. Quartz India, April 9. Accessed November 3, 2018. https://qz.com/india/1247197/cambridge-analytica-indias-bjp-and-congress-mined-voterspsychographic-data/ 


\section{About the Author}

\section{Sreekala Girija}

Sreekala Girija is a doctoral student in the Department of Communication at the University of Hyderabad in India. Her research interests include critical theory, political economy of media, technology and society. Her current research focuses on Internet-based journalism start-ups in India and their potential to democratise media space in India. 